\title{
Evaluation of Resource and Environmental Carrying Capacity of China's Rapid-Urbanization Areas-A Case Study of Xinbei District, Changzhou
}

\author{
Kaiyuan Li ${ }^{1,2,3}$, Xiaolong Jin ${ }^{1,2}$, Danxun Ma ${ }^{1,2}$ and Penghui Jiang ${ }^{1,2, *(D)}$ \\ 1 School of Geography and Ocean Science, Nanjing University, Nanjing 210023, China; \\ kaiyuanalex@berkeley.edu (K.L.); dg1727013@smail.nju.edu.cn (X.J.); MG1727111@smail.nju.edu.cn (D.M.) \\ 2 Jiangsu Provincial Key Laboratory of Geographic Information Science and Technology, Nanjing University, \\ Nanjing 210023, China \\ 3 Department of Landscape Architecture and Environmental Planning, Wurster Hall, Berkeley, CA 94720, USA \\ * Correspondence: jiangph1986@nju.edu.cn; Tel.: +86-25-83595336
}

Received: 28 February 2019; Accepted: 17 April 2019; Published: 21 April 2019

\begin{abstract}
The evaluation of resource and environmental carrying capacity (RECC) is the foundation for the rationale behind the arrangement of land spaces for production, living, and ecological uses. In this study, based on various natural, economic, and social factors, an integrated Multi-Factor assessment model was developed to evaluate the RECC of Xinbei district of Changzhou. Meanwhile, we also calculated the population carrying capacity estimation model restricted by food security. The study comprehensively analyzed the current status and land resource characteristics of a rapid urbanization area and the RECC restrictions for protection and development. The results indicate that the comprehensive carrying capacity of Xinbei showed distinct spatial heterogeneity, with a decreasing trend from the riverside protection area to urban areas, then to mountain areas. Combined with the secure food supply provided by future land resources, it was estimated that the population carrying index of Xinbei would be as high as 1.25 and 1.22 in 2035 and 2050, respectively, indicating that both years would experience a population overload. Therefore, an urgent adjustment to the structure and layout of territorial space and resources of the Xinbei District is necessary.
\end{abstract}

Keywords: urbanization; resource and environment carrying capacity; food security; population carrying capacity

\section{Introduction}

Since the 1980s, rapid economic growth and urbanization resulting from the Reform and Open Policy has led to a series of problems, such as rapid population growth, ecological environment degradation, traffic congestion, and resource shortage, causing a serious conflict between economic and social development, and the resources and environment [1-3]. As a result, a series of challenging problems concerning how to coordinate the relationship between resources, environment, ecology, social and economic development, and how to facilitate sustainable and green development of a regional economy based on source and environmental conditions has emerged [4,5]. Therefore, a comprehensive understanding of the local conditions and the biophysical limits of the environment and the environment carrying capacity (ECC) is crucial for the overall arrangements of the planning and construction of territorial space [6,7].

The concept of ECC is rooted in biology, ecology and demography, which is defined as the ability of a region's environment and resources to support the threshold of human activities for a specific period [8,9]. Therefore, it is a powerful tool for spatial and environment planning and management [10]. In China, Zeng (1998) first made comprehensive environmental research in 
Fujian Province and provided critical guidelines for the management of resources in a more green and healthy way [11]. Since then, the theory of ECC has been widely applied in environment planning and management and has played an important role in regional resource and environmental management and territorial spatial planning [6,12-16]. For example, based on results of regional water resource carrying capacity evaluation, Wang (2013) and Yang (2014) pointed out that rapid population growth could aggravate water resource crises and limit regional economic growth $[17,18]$. They also suggested that restrictive classification of water resources was required to guide rational regional development. Similarly, evaluations of the forest resource carrying capacity and eco-environment carrying capacity also revealed that environmental pollution and resource shortages restrict regional economic development [19-22]. All these studies have provided a theoretical basis for territorial spatial planning, post-disaster reconstruction, and sustainable development of the regional social economy.

The majority of existing studies in this field have focused on the evaluation of the carrying capacity of a single factor. However, as a system, a region requires comprehensive and balanced development of the economy, society, environment, and resources [23]. Therefore, a comprehensive evaluation of the regional resource and environmental carrying capacity (RECC) is necessary to investigate the interactive mechanisms between social and economic factors, and resource and environmental factors [10]. In addition, when selecting evaluation indices, the studies mentioned above were limited by subjective factors and data availability and were unable to fully consider all impact factors $[18,24,25]$. However, when selecting evaluation indices, multiple aspects such as resource size, economy and society, and ecological environment, should be considered [3,16].

With China currently in a critical stage of a new type of urbanization and ecological progress, land resources face the dual mandate of ensuring development and protecting ecology [2]. Therefore, a scientific and systematic evaluation of the regional RECC is urgently required to alleviate the resource restrictions on social and economic development and ensure resource supply as well as environmental and ecological security $[16,26]$. Meanwhile, with the implemented policy concerning the protection of the Yangtze river, it is necessary to carry out the evaluation of RECC, as to provide theoretical support for optimizing the development and use of territorial spaces and ensure environmental and ecological security.

This study selected Xinbei District in Changzhou as a study area because it has a special geographical location and fragile ecological environment. An integrated Multi-Factor assessment model was developed by incorporating various natural, economic, and social factors. By calculating the comprehensive RECC and population carrying capacity (PCC) estimation model restricted by food security of Xinbei District, our work expands on the evaluation method in a more comprehensive way and provides a more detailed analysis of obtained results. With the aim to provide a solid scientific basis for reasonable allocation of resources and environmental, and for sustainable development of the ecological environment, guiding regional territorial spatial planning, accordingly. The next section describes the study area. Section 3 presents data sources and the methods used in this study. Results analysis and recommendations are given in Sections 4 and 5, respectively. The final section presents our conclusions and discussion for the possible uncertainties and improvements in future study.

\section{Study Area}

Xinbei District is located in the northern part of Changzhou, Yangtze River Delta in China, with the Yangtze River in the north, and the Shanghai-Nanjing Railway in the south (Figure 1). This is a superior location due to its connection with cities such as Suzhou, Wuxi, and Zhenjiang, and is equidistant to the three megalopolises of Shanghai, Nanjing, and Hangzhou.

Xinbei District has three sub-districts and seven towns, namely Hehai Sub-district, Sanjing Sub-district, Longhutang Sub-district, Xinqiao Town, Xuejia Town, Chunjiang Town, Luoxi Town, Xixiashu Town, Menghe Town, and Benniu Town (Figure 1). At the end of 2017, the district's resident population was 691,900 , with an urbanization rate of $64.96 \%$. In 2017 , the district achieved a regional Gross Domestic Product (GDP) of 134.20 billion yuan, where the added value of the Primary industry 
was 2 billion yuan, the added value of the secondary industry was 69.415 billion yuan, and the added value of the tertiary industry was 62.605 billion yuan (Table 1). The ratio of the three industrial structures was 1.49:51.79:46.72 (Table 1). In 2017, the district earned a total fiscal revenue of 29.4 billion yuan, with a fixed assets investment of 87.28 billion yuan (Table 1). The per capita disposable income of urban residents was 52,407 yuan, with a yearly increase rate of $8.6 \%$ (Table 1 ). The per capita disposable income of rural residents was 26,753 yuan, with a yearly increase rate of $8.6 \%$ [27].
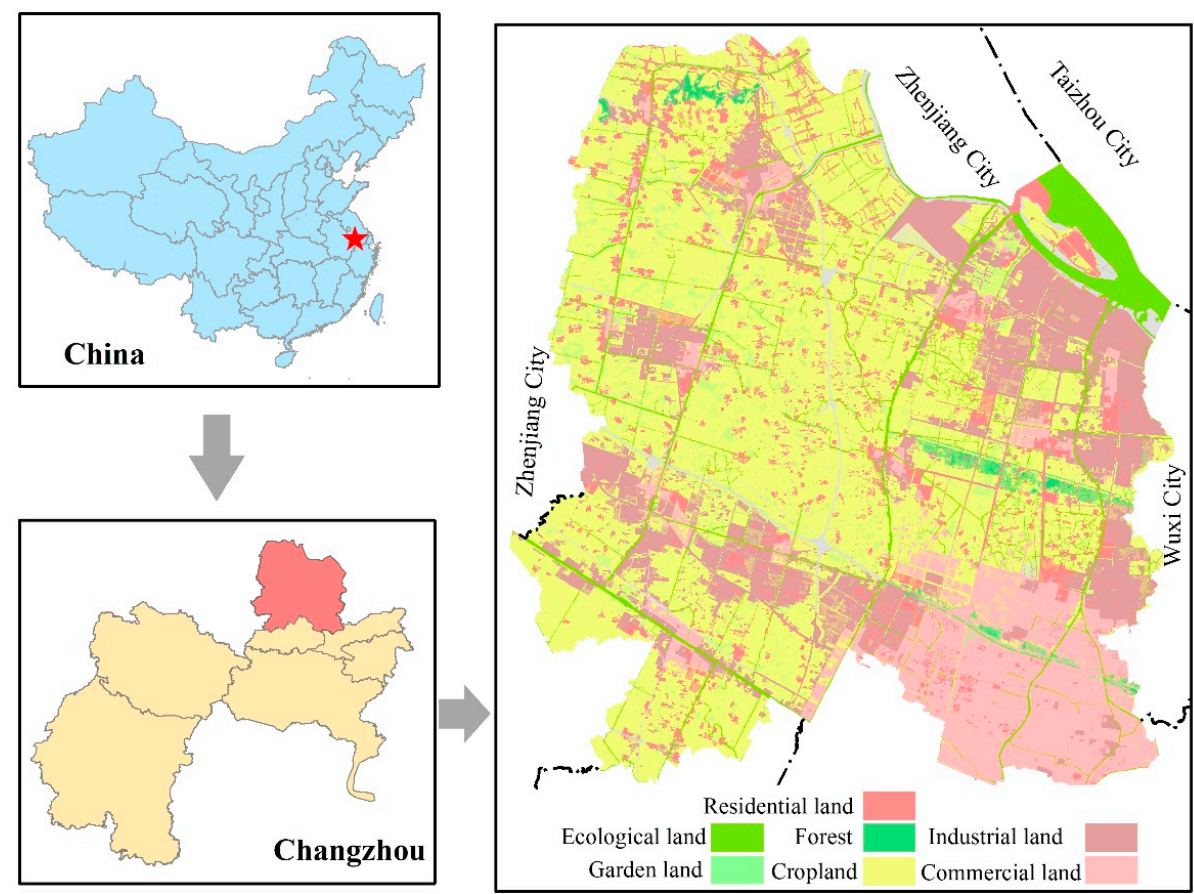

Figure 1. Geographical location and land use of the study area.

Table 1. Social-economic situation of Xinbei.

\begin{tabular}{ccc}
\hline Category & Factors & Value \\
\hline \multirow{2}{*}{ Gross Domestic Product } & Primary industry & 2 billion yuan $(1.49 \%)$ \\
\cline { 2 - 3 } & Secondary industry & 69.42 billion yuan $(51.79 \%)$ \\
\cline { 2 - 3 } Fiscal revenue & Tertiary industry & 62.61 billion yuan $(46.72 \%)$ \\
\cline { 2 - 3 } & Total fiscal revenue & 29.4 billion yuan \\
\hline \multirow{2}{*}{ Per capita disposable income } & Fixed assets investment & 87.28 billion yuan \\
\cline { 2 - 3 } & Urban residents & 52,407 yuan \\
\cline { 2 - 3 } & Rural residents & 26,753 yuan \\
\hline
\end{tabular}

The transportation in Xinbei District is convenient, as it has a three-dimensional bus, railway, waterway, and airway transportation system that radiates in all directions and connects to locations outside [28,29]. Shanghai-Nanjing Railway, Beijing-Shanghai High-speed Railway, Shanghai-Nanjing Expressway, 338 Provincial Highway, Changchen Road, and Jiangyi Expressway pass through the district, with the Changzhou Station of Beijing-Shanghai High-speed Railway located in the district. Xinbei District owns all the Yangtze River coastlines of Changzhou, providing the natural conditions needed to construct a deep-water port [30]. A national first-class open port, the Changzhou Port, has been constructed, with international ocean shipping lines in place. The Changzhou Airport located in the district has flights to more than 30 cities within China and abroad. Three rivers, namely Zaojiang River, Desheng River, and Xinmeng River, run through the district and connect the Beijing-Hangzhou Grand Canal and the Yangtze River. 


\section{Data Sources and Study Methods}

\subsection{Data Sources}

This study comprehensively considered various factors and indices that might affect the evaluation of regional RECC. The data used, such as land resource use status; farmland quality grade; and heavy metal concentration in soil along with the specific names, attributes, sources, and usage of data, are listed below in Table 2.

There are two types of datasets used in this study, the spatial datasets and the census data. The vector data were collected from the Changzhou Municipal Bureau of Land and Resources in Arcgis shaplefile format, which are mainly produced by manual survey. The vector data were fist masked by the administrative boundary of Xinbei district, then the topological error and the continuity of the data was inspected and corrected. Socioeconomic statistics were obtained from the "Statistical Yearbook of Changzhou City" using townships as the basic statistical unit. In addition, Inverse Distance Weighted (IDW) interpolation method was used to spatialize the census data.

Table 2. Data and their sources.

\begin{tabular}{|c|c|c|c|c|}
\hline Data Type & Data Name & Data Attribute & Data Source & Data Usage \\
\hline \multirow{4}{*}{ Land use data } & $\begin{array}{l}\text { Land use change data } \\
\text { between } 2009 \text { and } 2016\end{array}$ & Vector data & $\begin{array}{l}\text { Changzhou Municipal Bureau } \\
\text { of Land and Resources } \\
\text { (http://www.jsmlr.gov.cn/cz/) }\end{array}$ & $\begin{array}{l}\text { Analysing land use change } \\
\text { between } 2009 \text { and } 2016\end{array}$ \\
\hline & $\begin{array}{l}\text { Per capita land } \\
\text { area data }\end{array}$ & Statistical data & \multirow{3}{*}{$\begin{array}{c}\text { Changzhou Statistical } \\
\text { Yearbook } \\
\text { (http://tj.changzhou.gov.cn/) }\end{array}$} & $\begin{array}{l}\text { Resource carrying } \\
\text { capacity evaluation }\end{array}$ \\
\hline & Land use intensity data & Statistical data & & $\begin{array}{l}\text { Resource carrying } \\
\text { capacity evaluation }\end{array}$ \\
\hline & $\begin{array}{l}\text { Land output } \\
\text { benefit data }\end{array}$ & Statistical data & & $\begin{array}{l}\text { Resource carrying } \\
\text { capacity evaluation }\end{array}$ \\
\hline \multirow{3}{*}{$\begin{array}{l}\text { Farmland quality } \\
\text { grade data }\end{array}$} & $\begin{array}{l}\text { Farmland natural } \\
\text { grade data }\end{array}$ & Vector data & \multirow{3}{*}{$\begin{array}{l}\text { Changzhou Municipal Bureau } \\
\text { of Land and Resources } \\
\text { (http://www.jsmlr.gov.cn/cz/) }\end{array}$} & $\begin{array}{l}\text { Resource carrying } \\
\text { capacity evaluation }\end{array}$ \\
\hline & $\begin{array}{l}\text { Farmland use } \\
\text { grade data }\end{array}$ & Vector data & & $\begin{array}{l}\text { Resource carrying } \\
\text { capacity evaluation }\end{array}$ \\
\hline & $\begin{array}{c}\text { Farmland economic } \\
\text { grade data }\end{array}$ & Vector data & & $\begin{array}{l}\text { Resource carrying } \\
\text { capacity evaluation }\end{array}$ \\
\hline \multirow{7}{*}{$\begin{array}{l}\text { Heavy metal } \\
\text { content in soil data }\end{array}$} & $\begin{array}{l}\text { Cadmium content in } \\
\text { soil data }\end{array}$ & Vector data & \multirow{7}{*}{$\begin{array}{l}\text { Harmonized China Soil } \\
\text { Database } \\
\text { (http://vdb3.soil.csdb.cn/) }\end{array}$} & $\begin{array}{l}\text { Environmental carrying } \\
\text { capacity evaluation }\end{array}$ \\
\hline & $\begin{array}{l}\text { Chromium content in } \\
\text { soil data }\end{array}$ & Vector data & & $\begin{array}{l}\text { Environmental carrying } \\
\text { capacity evaluation }\end{array}$ \\
\hline & $\begin{array}{l}\text { Mercury content in } \\
\text { soil data }\end{array}$ & Vector data & & $\begin{array}{l}\text { Environmental carrying } \\
\text { capacity evaluation }\end{array}$ \\
\hline & $\begin{array}{l}\text { Lead content in } \\
\text { soil data }\end{array}$ & Vector data & & $\begin{array}{l}\text { Environmental carrying } \\
\text { capacity evaluation }\end{array}$ \\
\hline & $\begin{array}{l}\text { Arsenic content in } \\
\text { soil data }\end{array}$ & Vector data & & $\begin{array}{l}\text { Environmental carrying } \\
\text { capacity evaluation }\end{array}$ \\
\hline & $\begin{array}{l}\text { Copper content in } \\
\text { soil data }\end{array}$ & Vector data & & $\begin{array}{l}\text { Environmental carrying } \\
\text { capacity evaluation }\end{array}$ \\
\hline & $\begin{array}{l}\text { Zinc content in } \\
\text { soil data }\end{array}$ & Vector data & & $\begin{array}{l}\text { Environmental carrying } \\
\text { capacity evaluation }\end{array}$ \\
\hline \multirow{6}{*}{$\begin{array}{l}\text { Economic } \\
\text { development over } \\
\text { the years data }\end{array}$} & $\begin{array}{c}\text { GDP data of } \\
\text { primary industry }\end{array}$ & Statistical data & \multirow{6}{*}{$\begin{array}{c}\text { Changzhou Statistical } \\
\text { Yearbook } \\
\text { (http://tj].changzhou.gov.cn/) }\end{array}$} & $\begin{array}{l}\text { Population carrying } \\
\text { capacity estimation }\end{array}$ \\
\hline & $\begin{array}{c}\text { GDP data of } \\
\text { secondary industry }\end{array}$ & Statistical data & & $\begin{array}{l}\text { Population carrying } \\
\text { capacity estimation }\end{array}$ \\
\hline & $\begin{array}{l}\text { GDP data of } \\
\text { tertiary industry }\end{array}$ & Statistical data & & $\begin{array}{l}\text { Population carrying } \\
\text { capacity estimation }\end{array}$ \\
\hline & Per capita GDP data & Statistical data & & $\begin{array}{l}\text { Population carrying } \\
\text { capacity estimation }\end{array}$ \\
\hline & GDP data & Statistical data & & $\begin{array}{l}\text { Population carrying } \\
\text { capacity estimation }\end{array}$ \\
\hline & Population size data & Statistical data & & $\begin{array}{l}\text { Population carrying } \\
\text { capacity estimation }\end{array}$ \\
\hline
\end{tabular}


Table 2. Cont.

\begin{tabular}{|c|c|c|c|c|}
\hline Data Type & Data Name & Data Attribute & Data Source & Data Usage \\
\hline $\begin{array}{l}\text { Water resources } \\
\text { data }\end{array}$ & Water function data & Vector data & \multirow{3}{*}{$\begin{array}{l}\text { Changzhou Municipal Bureau } \\
\text { of Land and Resources } \\
\text { (http://www.jsmlr.gov.cn/cz/) }\end{array}$} & $\begin{array}{l}\text { Resource carrying } \\
\text { capacity evaluation }\end{array}$ \\
\hline $\begin{array}{c}\text { Ecological } \\
\text { environment data }\end{array}$ & $\begin{array}{l}\text { Ecological red line } \\
\text { definition data }\end{array}$ & Vector data & & $\begin{array}{l}\text { Environmental carrying } \\
\text { capacity evaluation }\end{array}$ \\
\hline $\begin{array}{l}\text { Geological } \\
\text { condition data }\end{array}$ & Land subsidence data & Vector data & & $\begin{array}{l}\text { Environmental carrying } \\
\text { capacity evaluation }\end{array}$ \\
\hline $\begin{array}{l}\text { Remote sensing } \\
\text { image data }\end{array}$ & $\begin{array}{l}\text { High-resolution aerial } \\
\text { images }\end{array}$ & Raster data & $\begin{array}{l}\text { Changzhou Municipal Bureau } \\
\text { of Land and Resources } \\
\text { (http://www.jsmlr.gov.cn/cz/) }\end{array}$ & Resource status analysis \\
\hline Land use plan data & $\begin{array}{c}\text { Basic farmland } \\
\text { protected area data }\end{array}$ & Vector data & $\begin{array}{l}\text { Changzhou Land Use Overall } \\
\text { Planning and Adjustment } \\
\text { Complete database } \\
\text { (http://www.jsmlr.gov.cn/cz/) }\end{array}$ & Identifying Land use type \\
\hline Grain data & $\begin{array}{l}\text { Per capita food } \\
\text { consumption }\end{array}$ & Statistical data & $\begin{array}{l}\text { World Bank Open Data (https: } \\
\text { //data.worldbank.org.cn/) }\end{array}$ & $\begin{array}{l}\text { Population carrying } \\
\text { capacity estimation }\end{array}$ \\
\hline
\end{tabular}

\subsection{Study Methods}

\subsubsection{Construction of an Evaluation Index System}

According to the principles of objective reality, restriction, operation, and application, combined with the analysis of the current resource and environmental situation. We constructed the criterion layers for the evaluation of resources, environment, and economy, with the aim of evaluating the comprehensive RECC of Xinbei District. As reported by a previous study, a number of natural and social factors were involved and selected to evaluate the RECC [22,31]. We then filtered the evaluation factors through multiple collinearity assessments, where any two factors with a correlation coefficient $>0.7$ were excluded. Table 3 presents the end results during the filtration.

Table 3. Weights of evaluation factors.

\begin{tabular}{|c|c|c|c|c|}
\hline Goal Layer & Criterion Layer & Weight & Factor Layer & Weights \\
\hline \multirow{21}{*}{$\begin{array}{l}\text { Evaluation of the } \\
\text { comprehensive } \\
\text { resource and } \\
\text { environmental } \\
\text { carrying capacity } \\
\text { of Xinbei District }\end{array}$} & \multirow{5}{*}{ A: Socioeconomic } & \multirow{5}{*}{0.0577} & A1: GDP per capita & 0.0078 \\
\hline & & & A2: Population size & 0.0160 \\
\hline & & & A3: Primary industry GDP & 0.0117 \\
\hline & & & A4: Secondary industry GDP & 0.0121 \\
\hline & & & A5: Tertiary industry GDP & 0.0101 \\
\hline & B: Ecological environment & 0.2178 & B1: Ecological red line & 0.2178 \\
\hline & C: Water environment & 0.2975 & C1: Water function partition & 0.2975 \\
\hline & D: Geological environment & 0.1888 & D1: Land subsidence & 0.1888 \\
\hline & \multirow{7}{*}{ E: Soil environment } & \multirow{7}{*}{0.0823} & E1: Cadmium pollution grade & 0.0098 \\
\hline & & & E2: Zinc pollution grade & 0.0067 \\
\hline & & & E3: Chromium pollution grade & 0.0094 \\
\hline & & & E4: Copper pollution grade & 0.0093 \\
\hline & & & E5: Lead pollution grade & 0.0086 \\
\hline & & & E6: Arsenic pollution grade & 0.0092 \\
\hline & & & E7: Mercury pollution grade & 0.0047 \\
\hline & \multirow{3}{*}{ F: Soil quality } & \multirow{3}{*}{0.0523} & F1: Farmland use grade & 0.0127 \\
\hline & & & F2: Farmland economic grade & 0.0204 \\
\hline & & & F3: Farmland natural grade & 0.0192 \\
\hline & \multirow{3}{*}{ G: Land resources } & \multirow{3}{*}{0.1036} & G1: Land use intensity & 0.0092 \\
\hline & & & G2: Land output benefits & 0.0973 \\
\hline & & & G3: Per capita land area & 0.0271 \\
\hline
\end{tabular}




\subsubsection{Determination of the Weights of Indices}

In this study, the weights of the indices were determined by AHP (Figure 2). The principles are listed as follows:

Definition 1. Suppose $W_{0}$ is a m-dimensional static constant weight factor and sums to 1 .

$$
W_{0}=\left(W_{1}^{0}, W_{2}^{0}, \cdots, W_{m}^{0}\right) \in(0,1]^{m} ; \text { and } \sum_{i=1}^{m} W_{i}^{0}=1
$$

Definition 2. There exists ma W. Suppose it is an m-dimensional local variable weight factor. In case both of the following conditions are satisfied: (1) The sum of the weights is equal to 1; and (2) Local penalty-incentive: for arbitrarily $i$, there exists $a_{i}$, if $W_{i}(X)$ about $x_{i}$ monotonically decreases between 0 to $a_{i}$, then $W(X)$ is called a continuous local variable weight vector.

Definition 3. There exists mapping $S$. Suppose it is an m-dimensional local state variable weight factor. In case the following conditions are satisfied: for arbitrarily $i$, there exists $a_{j}$, $b_{j}$ belongs to $0-1$, and $a_{j}>b_{j}$; for $a$ static constant weight vector $W_{0}$ that satisfy Equation (5), and $x_{i}$ monotonically decreases between 0 to $b_{j}$, but monotonically increases between $a_{j}$ to 1 , then $S(X)$ is called a continuous local state variable weight vector.

$$
W_{i}(X)=\left[W_{i}^{0} S_{i}(X)\right] /\left[\sum_{i=1}^{m} W_{i}^{0} S_{i}(X)\right] \text { and } W_{0}=\left(W_{1}^{0}, W_{2}^{0}, \cdots, W_{m}^{0}\right)
$$

Theorem 1. There exists mapping $S$; suppose it is an m-dimensional local state variable weight vector, and $W_{0}$ is a random static constant weight factor. If $S(X)$ satisfies the condition described in Definition 3, then for $i$, there exists the following Equation (3):

$$
\frac{W_{i}^{0} S_{i}(X)}{\sum_{i=1}^{m} W_{i}^{0} S_{i}(X)} \Delta\left(\frac{W_{1}^{0} S_{1}(X)}{\sum_{i=1}^{m} W_{i}^{0} S_{i}(X)}, \frac{W_{2}^{0} S_{2}(X)}{\sum_{i=1}^{m} W_{i}^{0} S_{i}(X)}, \cdots, \frac{W_{m}^{0} S_{m}(X)}{\sum_{i=1}^{m} W_{i}^{0} S_{i}(X)}\right)
$$

Therefore, we can derive the variable weight formula, which is as follows:

$$
W_{i}(X)=\frac{W_{i}^{0} S_{i}(X)}{\sum_{i=1}^{m} W_{i}^{0} S_{i}(X)}
$$

Here, $X$ denotes the data vector of each evaluation index; $S_{i}(X)$ denotes the local state variable weight vector; and $W_{i}$ denotes the base weight vector.

From Equation (5), it is noted that on the basis of the base weight vector $W_{i}$, the variable weight vector $W_{i}(X)$ realizes weight changes through the local state variable weight vector $S_{i}(X)$. There are many common methods that can be applied to determine the state variable weight vectors, for example, the empirical formula. Based on comprehensive considerations, this paper adopted the segment penalty variable weight function approach, the details of which are shown in Equation (2).

$$
S_{i}(X)=\left\{\begin{array}{l}
\frac{b-1}{\beta} X+1, X<\beta \\
\frac{b-a}{(\alpha-\beta)^{2}}\left(X_{i}-\alpha\right)^{2}+a, X \in[\beta, \alpha] \\
a, X>\alpha
\end{array}\right.
$$


It can be seen from Equation (2) that the segment penalty variable weight function approach divides the penalty interval into three parts: the strong-penalty interval. $X<\beta$, the initial-penalty interval $\beta<X<\alpha$, and the non-penalty interval $X>\alpha$. The parameters $a$ and $b$ in the equation can be adjusted according to the evaluation requirement. Equations (1) and (2), combined with the base weight, can then determine the variable weight $W_{i}$ of each evaluation factor (Table 3).



Figure 2. Weight Determination Workflow.

\subsubsection{Establishment of an Integrated Multi-Factor Assessment Model}

We based our theory on human-environment relationship theory; and by combining relevant mathematical knowledge, the study aimed to explain the factors and indices that affected the regional RECC [27,30]. Analytic Hierarchy Process (AHP) was used to quantitatively and qualitatively evaluate the RECC. The AHP is a structured technique for organizing and analyzing complex decisions, based on mathematics and psychology. It was developed by Thomas L. Saaty in the 1990s and has been extensively studied and refined since then [2,19,28,32].

The establishment of the model mainly consisted of three steps: index system construction, index weight determination, and evaluation result analysis as shown in Figure 3. First, based on the constructed index system, 21 explanatory factors representing natural and social features were used. The weight of each evaluation factor determined by AHP was converted into dimensionless indices. Then, the result was the construction of an integrated Multi-Factor assessment model for the evaluation of Xinbei District's RECC. Finally, according to the meaning of the evaluation object determined by comprehensive evaluation, the results were classified into different levels to reflect its capacity in sustainable development of the ecological environment.

Considering data availability and the size of the study area, the study used a grid size of $100 \mathrm{~m} \times 100 \mathrm{~m}$ for the calculation and analysis. For this grid size, the evaluation results of Xinbei District's comprehensive RECC were obtained by overlay analysis of weighted dimensionless factors.

\subsubsection{Estimation Model of PCC Based on Land Resources}

The PCC based on food supply could be calculated on the basis of thr food security of the current population and the future population peak. The maximum population capacity based on future regional food supply was estimated according to the future food supply and food consumption standard [33]. The estimation model of the carrying capacity is as follows:

$$
\begin{gathered}
\mathrm{LCC}=\mathrm{G} /\left(\mathrm{w}^{*} \mathrm{G}_{\mathrm{pc}}\right) \\
\mathrm{LCCI}=\mathrm{P} / \mathrm{LCC}
\end{gathered}
$$


Here, LCC is the total PCC according to farmland resources (person); G, W, and $\mathrm{G}_{\mathrm{pc}}$ are the regional total production of domestic food supply $(\mathrm{kg})$, self-sufficiency rate of food $(\%)$, and the per capita food consumption standard ( $\mathrm{kg} /$ person), respectively. While LCCI denotes PCC index, and P is the current population.

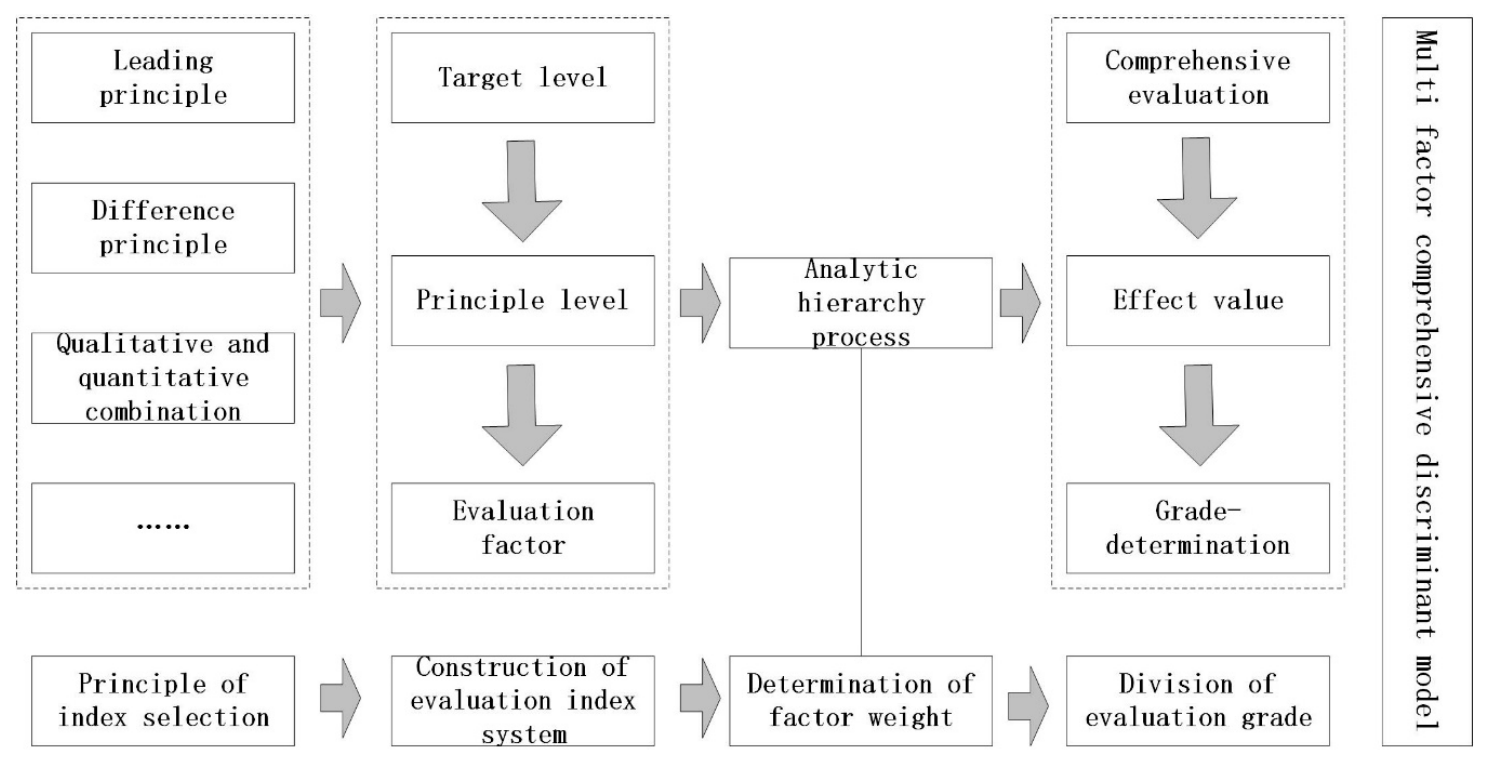

Figure 3. The multi-index multi-factor synthetic discriminant model for the evaluation of the RECC.

The lower the population carrying capacity index, the higher the food surplus rate, indicating a more balanced relationship between the population and food supply of the region. On the contrary, the higher the PCC index, the more overloaded the regional population. Based on the PCC index, the carrying capacity states were classified into three levels: food surplus, balanced, and population overload. Moreover, according to the natural breaks of the variable distribution, they were further divided into eight sub-levels depending on the degree of surplus or overload (Table 4).

In this study, the method used to estimate the PCC on the basis of land resources, includes the estimation of the total food supply; hence, the total domestic food consumptions in 2035 and 2050 are estimated by considering the overall seed and industrial food consumption needs. Then, the per capita food consumptions in 2035 and 2050 are determined on the basis of the existing domestic food consumption status of residents and relevant planning. The future regional PCC is then estimated based on the results.

Table 4. Evaluation standards for the classification of the PCC state based on land resources.

\begin{tabular}{ccc}
\hline \multirow{2}{*}{ Man-Food Relationship } & $\begin{array}{c}\text { Land Resource Carrying } \\
\text { Capacity Index (LCCI) }\end{array}$ \\
\hline \multirow{2}{*}{ Food surplus } & Major surplus & $\mathrm{LCCI} \leq 0.5$ \\
\cline { 2 - 3 } & Moderate surplus & $0.5<\mathrm{LCCI} \leq 0.75$ \\
\cline { 2 - 3 } Balanced & Minor surplus & $0.75<\mathrm{LCCI} \leq 0.875$ \\
\cline { 2 - 3 } & Balanced, with slight surplus & $0.875<\mathrm{LCCI} \leq 1$ \\
\hline \multirow{2}{*}{ Population overload } & Minor overload & $1<\mathrm{LCCI} \leq 1.125$ \\
\cline { 2 - 3 } & Moderate overload & $1.125<\mathrm{LCCI} \leq 1.25$ \\
\cline { 2 - 3 } & Major overload & $1.25<\mathrm{LCCI} \leq 1.5$ \\
\hline
\end{tabular}




\section{Result Analysis}

\subsection{Evaluation of the Comprehensive RECC of Xinbei District}

On the basis of the integrated Multi-Factor assessment model, the results of the comprehensive RECC of Xinbei District are presented in Figure 4.

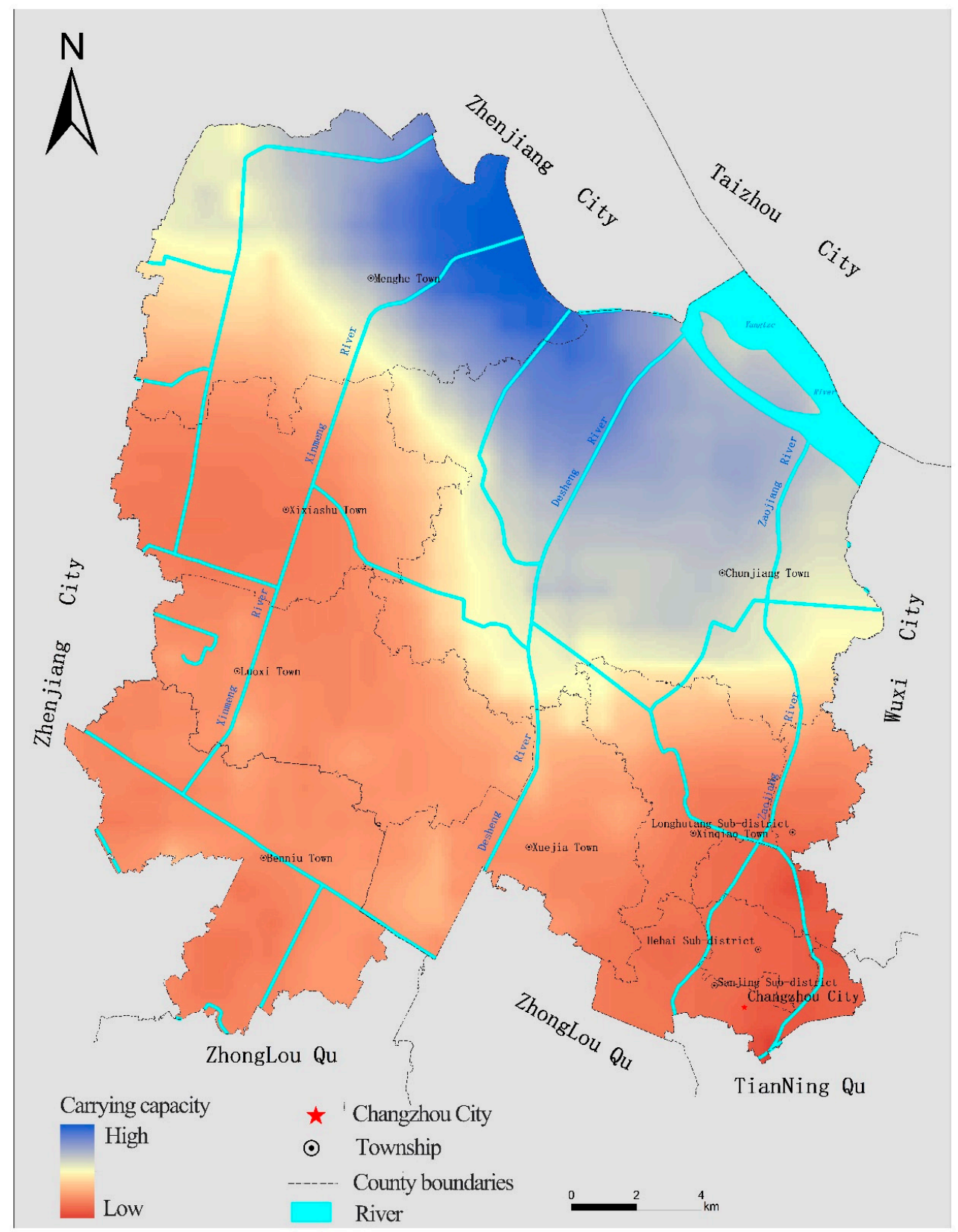

Figure 4. Evaluation results of the comprehensive RECC of Xinbei District.

The results indicate that in general, the comprehensive RECC of Xinbei District is high, with an overall decreasing trend seen from the northeast region along the Yangtze River to the southwest region. This is because the region along the river has abundant water and land resources, along with complete infrastructures. The superior natural and location conditions lead to not only relatively high comprehensive RECC, but also larger development space. On the contrary, infrastructures such as transportation are weak in some areas in the south-western region of Xinbei District, due to their long distances from the central area. As a result, despite their superior ecological environment, 
these areas are still relatively ecologically vulnerable. Being susceptible to development, these areas cannot guarantee sustainable use, causing substantial pressure on the regional ecological environment. Therefore, the comprehensive RECC of this region is lower than that of other regions. Alternatively, despite its complete infrastructures and after many years of construction and development, the northern new city of Changzhou located in the southern part of Xinbei District cannot afford further construction and development activities due to a poor ecological environment, high population, and construction density. Consequently, the comprehensive RECC of the northern new city is also low.

\subsection{Estimation of the PCC of Xinbei District Based on Land Resources}

According to the estimated value of total food supply, total domestic food consumptions and the overall seed and industrial food consumption needs, future regional PCC is then obtained. The detailed steps are as follows:

\subsubsection{Total Supply for Domestic Food Consumption}

1. Food cultivation area estimation. By calculating the average farmland areas of Xinbei District from the data collected between 2007 and 2016, the farmland areas in 2035 and 2050 are estimated, which are 26,699 hectares and 26,592 hectares, respectively.

2. Food yield per unit area estimation. Based on the total food production output and the farmland area of Xinbei District reported in the 2007-2016 Statistical Yearbook (Figure 5), the food yield per unit area is calculated. Since 2007, the food yield per unit area has been growing steadily (Figure 5). However, presently, the food yield per unit area of Xinbei District is already high. Under the currently predictable food production conditions, it is expected that future yield per unit area is not likely to increase significantly. Therefore, the food yield per unit area in 2035 is estimated by calculating the average yield per unit area of the recent 10 years, which is $5445.72 \mathrm{~kg} / \mathrm{ha}$; the food yield per unit area in 2050 is estimated by calculating the average yield per unit area of the recent 5 years, which is $5625.57 \mathrm{~kg} / \mathrm{ha}$.

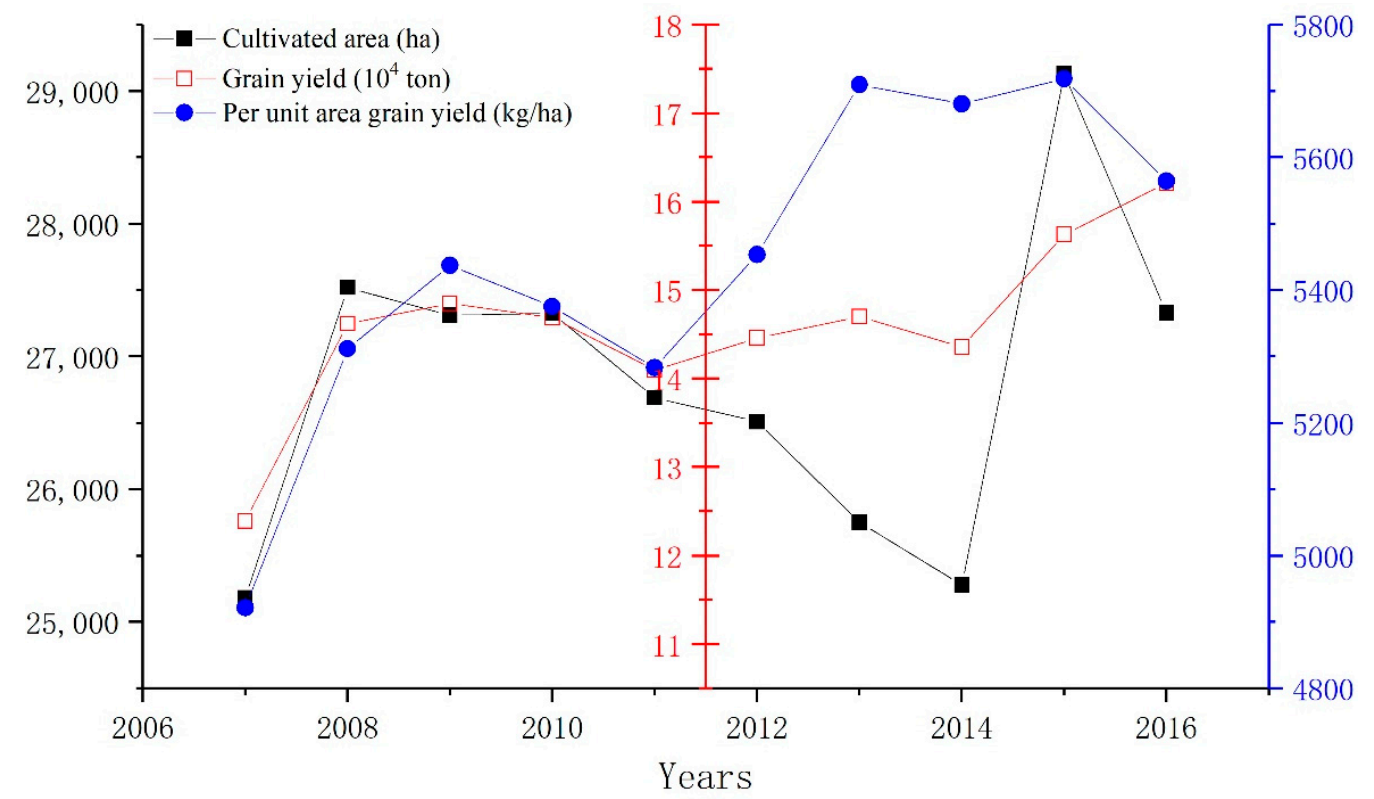

Figure 5. Food production trend of Xinbei District (2007-2016).

3. Total food production estimation. According to the above estimation of farmland area and food yield per unit area, the total food production of Xinbei District in 2035 and 2050 is estimated, as shown in Table 4. 
4. Seed food consumption estimation. The seed food consumption depends mainly on the farmland area and the number of seeds used per unit area. Since the number of seeds used per unit area barely changes between years, a value of $113 \mathrm{~kg} / \mathrm{ha}$ based on existing research results is used to calculate the seed food consumption. Then, the seed food consumption of Xinbei District in 2035 and 2050 is estimated according to the farmland area estimated above, as shown in Table 4.

5. Industrial food consumption estimation. Here the industrial food consumption mainly refers to food used for brewing, seasoning production, and feed production, while excluding processed food products and cakes. Based on the industrial product manufacturing statistics from the Statistical Yearbook (2010-2016) of Xinbei District, along with the published conversion ratio of the production volume of various industrial products to the amount of food consumed, the industrial food consumption between 2010 and 2016 is calculated, with a conversion ratio of 1:2.3 for liquor, 1:0.172 for beer, 1:24 for MSG, and 1:0.7 for forage. SPSS is then used to perform curve estimation on the converted industrial food consumption data of Xinbei District between 2010 and 2016. The calculated $R^{2}$ indicates that linear regression is the most fitting, with an $R^{2}$ value of 0.758. The industrial food consumption of Xinbei District in 2035 and 2050 is then estimated based on the following prediction formula:

$$
y=12731 x+54348
$$

Here, $x$ refers to the 2010-2016 time period, and $y$ refers to the industrial food consumption of the corresponding year. The industrial food consumption of Xinbei District in 2035 and 2050 is then estimated based on the above prediction model, as shown in Table 4.

6. Domestic food consumption estimation. According to the above estimation results, the domestic food consumption for the regional population of each county and town is calculated by subtracting the seed and industrial food consumptions from the total food supply. The results are listed in Table 4.

\subsubsection{Per Capita Food Consumption}

According to the goal of building an all-round moderately prosperous society in Jiangsu Province, by 2015 , the province should have achieved a moderately prosperous society at the county level; furthermore, by 2020, the whole province should basically achieve modernization. Based on this goal and the current development status of Changzhou, where Xinbei District is located, it is expected that Xinbei District will achieve a wealthy living standard by 2020. The China Economic Bulletin issued by the World Bank has predicted that China's per capita food consumption will reach $479 \mathrm{~kg}$ in 2035 and $497 \mathrm{~kg}$ in 2050. According to the food consumption required by a wealthy living standard and the prediction from the World Bank, the per capita food consumption of Xinbei District has been determined (Table 5).

\subsubsection{Estimation of the PCC of Xinbei District}

Based on the above predictions of domestic food consumption, per capita food consumption, and food self-sufficiency rate, the PCC of Xinbei District is estimated (Table 5). From the estimation results, it is seen that the food supply of Xinbei District can support a population of 667,544 in 2035 and a population of 769,711 in 2050. The PCC estimation results are then compared to the population prediction results adopted during the planning stage (Table 6). 
Table 5. Food consumption predictions for all uses.

\begin{tabular}{|c|c|c|c|c|c|c|}
\hline Type & $\begin{array}{l}\text { Calculation } \\
\text { Index/Formula }\end{array}$ & 2035 & 2050 & $\begin{array}{l}\text { Capacity } \\
\text { Estimation }\end{array}$ & 2035 & 2050 \\
\hline \multirow{2}{*}{$\begin{array}{l}\text { Total food supply } \\
\text { estimation } \\
\text { (G) }\end{array}$} & $\begin{array}{l}\text { Food cultivation area } \\
\text { (Hectare) }\end{array}$ & 26,699 & 26,592 & \multirow{2}{*}{$\begin{array}{l}\text { Total food supply } \\
\text { (Ten thousand ton) }\end{array}$} & \multirow[b]{2}{*}{14.5395} & \multirow[b]{2}{*}{14.9595} \\
\hline & $\begin{array}{l}\text { Food yield per unit area } \\
\qquad(\mathrm{kg} / \mathrm{ha})\end{array}$ & 5445.72 & 5625.57 & & & \\
\hline $\begin{array}{l}\text { Seed food consumption } \\
\text { estimation } \\
\text { (S) }\end{array}$ & $\begin{array}{l}\text { Food cultivation area } \\
\text { (Hectare) }\end{array}$ & 26,699 & 26,592 & $\begin{array}{c}\text { Seed food } \\
\text { consumption (Ton) }\end{array}$ & 3016.98 & 3004.89 \\
\hline \multirow{4}{*}{$\begin{array}{l}\text { Industrial food } \\
\text { consumption estimation } \\
\text { (F) }\end{array}$} & Liquor & \multicolumn{2}{|c|}{$1: 2.3$} & \multirow{4}{*}{$\begin{array}{l}\text { Industrial food } \\
\text { consumption } \\
\text { (Ton) }\end{array}$} & \multirow{4}{*}{67,079} & \multirow{4}{*}{79,810} \\
\hline & Beer & & & & & \\
\hline & Feed production & \multicolumn{2}{|c|}{$1: 0.7$} & & & \\
\hline & MSG & \multicolumn{2}{|c|}{$1: 24$} & & & \\
\hline $\begin{array}{l}\text { Domestic food } \\
\text { consumption estimation } \\
\text { (L) }\end{array}$ & \multicolumn{3}{|c|}{$\mathrm{L}=\mathrm{G}-\mathrm{S}-\mathrm{F}$} & $\begin{array}{l}\text { Domestic food } \\
\text { consumption } \\
\text { (Ton) }\end{array}$ & 75,299 & 66,780 \\
\hline \multirow{2}{*}{$\begin{array}{c}\text { Per capita food } \\
\text { consumption estimation }\end{array}$} & $\begin{array}{l}\text { Wealthy living standard } \\
(\mathrm{kg} / \text { person*year })\end{array}$ & 461 & 460 & \multirow{2}{*}{$\begin{array}{l}\text { Per capita food } \\
\text { consumption } \\
(\mathrm{kg} / \text { person*year })\end{array}$} & \multirow{2}{*}{470} & \multirow{2}{*}{482} \\
\hline & $\begin{array}{l}\text { World Bank prediction } \\
\text { (kg/person*year) }\end{array}$ & 479 & 497 & & & \\
\hline
\end{tabular}

Table 6. PCC estimations.

\begin{tabular}{cccccc}
\hline Type & $\mathbf{2 0 3 5}$ & $\mathbf{2 0 5 0}$ & Type & $\mathbf{2 0 3 5}$ & $\mathbf{2 0 5 0}$ \\
\hline $\begin{array}{c}\text { Population based on } \\
\text { food supply }\end{array}$ & 66.7544 & 76.9711 & $\begin{array}{c}\text { Population } \\
\text { carrying } \\
\text { capacity index }\end{array}$ & 1.25 & 1.22 \\
\hline Predicted population & 83.9634 & 94.3234 & & \\
\hline
\end{tabular}

Using the estimation results of the PCC based on food supply, the PCC index of Xinbei District for the years 2035 and 2050 is calculated (Table 6). From the results, it is seen that in both 2035 and 2050, Xinbei District will be in a population overload status, although the pressure on the carrying capacity will be less in 2050 than in 2035.

\section{Recommendations Based on the Evaluation of RECC}

\subsection{Land Rearrangement and Spatial Planning Strategies}

\subsubsection{Establishing a Dynamic Monitoring and Early Warning Mechanism for the RECC}

The Integrated Reform Plan for Promoting Ecological Progress (2015) released by the Chinese government proposes to 'establish monitoring and early warning mechanisms for RECC and takes measures to place restrictions on regions which have exceeded their carrying capacities of water and land resources and environmental capacity'. Therefore, this study first recommends establishing dynamic monitoring mechanisms for RECC and then uses it as a scientific basis for important strategic goals, in order to effectively implement a control system for natural resource use.

\subsubsection{Define Territorial Control Space Based on the RECC}

We recommend rectifying the restrictive factors for land resources, based on the resource and environmental background as well as the RECC status, in order to reduce the restrictions of resource and environmental factors on land use. Furthermore, it is necessary to continuously improve the restrictive factors for the RECC and the regional development, in order to increase the RECC, and to ease the restrictions of resources and environment on economic and social development. 


\subsection{Layout of Land Use}

Based on the evaluation results of its RECC at both the county and town (neighbourhood) levels, Xinbei District is divided into: development area to be optimized and upgraded; moderate development area; key expansion area; riverside protection area; (Figure 6).

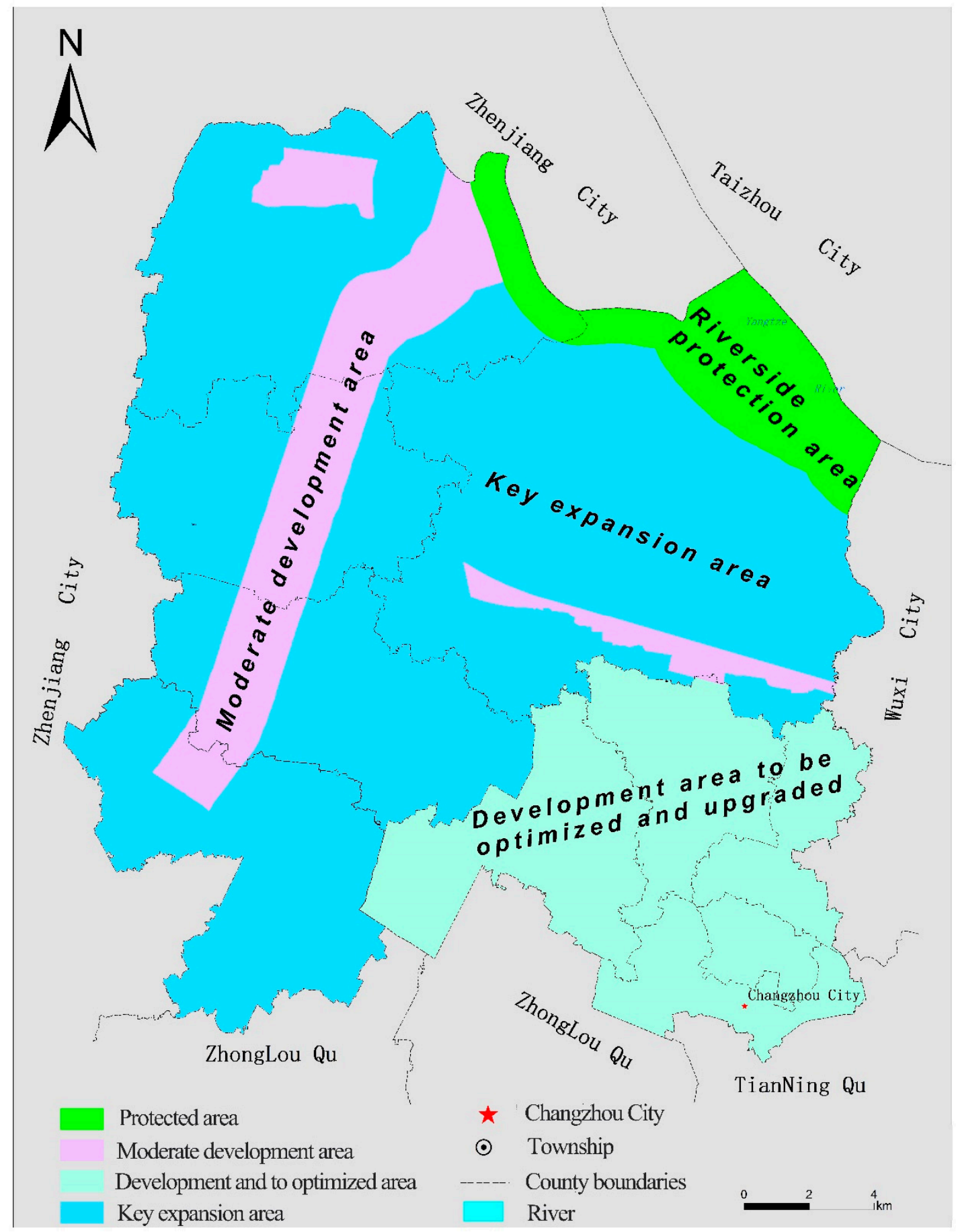

Figure 6. Recommended layout of land use of Xinbei District.

\subsubsection{The Development Area to Be Optimized and Upgraded}

This area mainly includes Xinqiao Town, Xuejia Town, Sanjing Sub-district, Hehai Sub-district, and Longhutang Sub-district. This area has inherited the city's history and is a landmark that highlights 
the city's charm. Moreover, it is also the main area for innovation vitality and service economy development. Therefore, for this modern urban area with high-end elements and comprehensive service functions, development should be focused on modern service industries, high-tech industries, and advanced manufacturing industries, in order to promote the transformation of the area's industrial structure to a high-end, high-efficiency, and high-added-value structure. The economic development density and industrial efficiency should be improved for the area to take a leading role in establishing an intensive and efficient economic development mode. In addition, by further increasing the level of city-industry integration and improving the service function and the comprehensive carrying capacity of the city (town), as well as enhancing its population agglomeration function and raising the overall population quality, this region can be converted into an area with the most developed economy, the densest population, and the most comprehensive functions.

\subsubsection{The Moderate Development Area}

Moderate development area is a concentrated place for special economy, a key area for industrial upgrade and a breakthrough area for city-industry integration. This area is mainly located on both sides of the Xinmeng River. Depending on the characteristics of each city and town, this study encourages the development of modern service industries such as eco-tourism, modern logistics, and commerce and trade, as well as characteristic and advantageous agriculture. In addition, advanced manufacturing industries allowed within the RECC can be developed based on the local conditions, in order to promote an agglomerated, diversified, and high-end development of manufacturing industries, and achieve a concentrated and agglomerated development pattern. Meanwhile, the intensity and scale of the development should be rationally controlled, the protection and repair of the ecological environment strengthened, and the comprehensive service facilities and service levels of cities and towns improved. This would enhance their ability to absorb the surrounding rural population, which would lead to significant breakthroughs in city-industry integration.

\subsubsection{The Key Expansion Area}

Key expansion area is an important vehicle for the new type of industrialization and urbanization, a key support for economic development and a critical junction point for the new type of urbanization and rural-urban development integration. This area includes Menghe Town, Chunjiang Town, Xixiashu Town, Luoxi Town, and Benniu Town. For this area, it is recommended that while improving infrastructure and public services, urban service functions should be enhanced, more jobs created, and institutional barriers for farmers to enter city should be removed, enabling the area to absorb emigrant population and rural transferred population on a larger scale. Meanwhile, advanced manufacturing industries and productive service industries should be actively developed, the construction of characteristic industry bases and industry clusters reinforced, and the allocation of major manufacturing projects to the key expansion area guided, in order to strengthen the expansion of economy and accelerate its transformation and advancement.

\subsubsection{The Riverside Protection Area}

Riverside protection area is mainly located in the 1-km buffer zone of the Yangtze River. In this area, large-scale industrialization and urbanization development should be restricted, while space for agricultural production should be reasonably expanded. No further expansion should be allowed for the existing industrial concentration areas; instead, their integration and retrieval should be encouraged. Additionally, the development of eco-tourism should be promoted. The addition of new construction space should be controlled, the space for modern agriculture and eco-tourism reasonably preserved, and the ecological space moderately increased. The population should be guided to migrate to areas such as the major development area, the moderate development area, and the key expansion area while a conscious, voluntary, and smooth migration should be guaranteed. 


\section{Discussion and Conclusions}

This study applied an integrated Multi-Factor assessment model to evaluate the environmental carrying capacity of Xinbei District in Changzhou. Generally, the comprehensive results show a declining trend from the northeast region along the Yangtze River to the southwest region with the mountainous area. In contrast, it shows lower comprehensive results in central Xinbei District. The results of this study are consistent with Clarke (2002) and Yang (2015) [18,34]. Areas with higher environmental carrying capacity are always associated with abundant natural resources [30]. While the mountainous areas, which were hindered by poor transportation and vulnerable environment, are supposed to bear lighter human activities [15]. In the light of the special natural environment of Xinbei, the northeast part of the district should accord with a high priority when planning for industries and cites. Meanwhile, a series of environmental protection measurements must be implemented along the Yangtze River to further reduce the volume of pollutant discharge.

A variety of environmental carrying capacity relate to different aspect of natural resources have been made by a previous study. For example, Wang (2000) and Prato (2009) carried out the ecological carrying capacity for protected areas in Heihe river basin, and regional, urban, social, cultural, and tourism carrying capacity were also implemented [12-14,35-37]. However, the evaluation of carrying capacity herein gives more emphasis on resource, environmental, and population. More comprehensive indicators such as cultural and atmospheric assimilative capacity should be considered in future study. In addition, the changes of policies and regulations promulgated by local government are not involved in the evaluation system, which could possibly guide the regional development in a new direction and affect the results of environmental carrying capacity accordingly [24,28]. It is urgent to incorporate these factors if such data are available in more detailed information.

Our results indicate that the resources and environmental carrying capacity displays a pattern of spatial heterogeneity, but maintained it at an acceptable level. This measurement system is useful and applicable to guide the layout of land use and the reasonable allocation of resource and environmental, guaranteeing the sustainable, green development of spatial management.

Author Contributions: P.H. designed the research. K.Y. wrote the manuscript, X.L. and D.X. processed the data. P.H., K.Y., X.L. and D.X. provided comments and suggestions regarding the manuscript, and contributed to the writing and discussion.

Funding: This work was supported by the Natural Science Foundation of Jiangsu Province of China (BK20180348), National Natural Science Foundation of China (No. 41801298), Fundamental Research Funds for the Central Universities (No. 020914380057), China Scholarship Council and the “Double-Creation Plan" of Jiangsu Province.

Acknowledgments: We thank Haoqing Tang from the School of Geography and Ocean Science, Nanjing University for assistance during this study. We also thank the editor and reviewers for their valuable comments on this manuscript.

Conflicts of Interest: The authors declare no conflict of interest.

\section{References}

1. Lu, D.D.; Fan, J.; Liu, W.D.; Ji, X.C.; Mu, X.W. Regional Space, Function and Development of China; China Land Press: Beijing, China, 2011. (In Chinese)

2. Zhang, B.C.; Guo, F. Studies on the carrying capacity of natural resources. Econ. Surv. 2006, 6, 22-25. (In Chinese)

3. Tang, B.J.; Hu, Y.; Li, H.N.; Yang, D.W.; Liu, J.P. Research on comprehensive carrying capacity of Beijing-Tianjin-Hebei region based on state-space method. Nat. Hazards 2016, 84, 113-128. [CrossRef]

4. Saveriades, A. Establishing the social tourism carrying capacity for the tourist resorts of the east coast of the Republic of Cyprus. Tour. Manag. 2000, 21, 147-156. [CrossRef]

5. Santoso, E.B.; Erli, H.K.D.M.; Aulia, B.U.; Ghozali, A. Concept of Carrying Capacity: Challenges in Spatial Planning. Procedia Soc. Behav. Sci. 2014, 135, 130-135. [CrossRef]

6. Godschalk, D.R.; Parker, F.H. Carrying capacity: A key to environmental planning? J. Soil Water Conserv. $1975,235,23-28$. 
7. Baldwin, J.H. Assessment of Environment Carrying capacity in Berkeley. J. Environ. Plan. Manag. 1985, 76, 234-239.

8. Kang, P.; Xu, L. Water environmental carrying capacity assessment of an industrial park. Procedia Environ. Sci. 2012, 13, 879-890. [CrossRef]

9. Świąder, M.; Szewrański, S.; Kazak, J. Foodshed as an example of preliminary research for conducting environmental carrying capacity analysis. Sustainability 2018, 10, 882. [CrossRef]

10. Liu, R.Z.; Borthwick, A.G.L. Measurement and assessment of carrying capacity of the environment in Ningbo, China. J. Environ. Manag. 2011, 92, 2047-2053. [CrossRef]

11. Zeng, W.H.; Wang, H.D.; Xue, J.Y.; Ye, W.H.; Guan, B.R. Theory of environment carrying capacity and it's application of environmental planning on Meizhou Bay. China Environ. Sci. 1998, S1, 71-74.

12. Daily, G.C.; Ehrlich, P.R. Socioeconomic Equity, Sustainability, and Earth's Carrying Capacity. Ecol. Appl. 1996, 6, 991-1001. [CrossRef]

13. Yu, D.-L.; Mao, H.-Y. Regional carrying capacity: Case studies of Bohai Rim area. J. Geogr. Sci. 2002, 12, 177-185.

14. Oh, K.; Jeong, Y.; Lee, D.; Lee, W.; Choi, J. Determining development density using the Urban Carrying Capacity Assessment System. Landsc. Urban Plan. 2005, 73, 1-15. [CrossRef]

15. Deng, W. Discussion on mountain area resource and environment carrying capacity. Geogr. Res. 2010, 28, 952-961.

16. Feng, Z.; Sun, T.; Yang, Y.; Yan, H. The Progress of Resources and Environment Carrying Capacity: From Single-factor Carrying Capacity Research to Comprehensive Research. J. Res. Ecol. 2018, 9, 125-134.

17. Wang, S.; Yang, F.L.; Xu, L.; Du, J. Multi-scale analysis of the water resources carrying capacity of the Liaohe Basin based on ecological footprints. J. Clean. Prod. 2013, 53, 158-166. [CrossRef]

18. Yang, J.; Lei, K.; Khu, S.; Meng, W. Assessment of Water Resources Carrying Capacity for Sustainable Development Based on a System Dynamics Model: A Case Study of Tieling City, China. Water Resour. Manag. 2015, 29, 885-899. [CrossRef]

19. Specht, P.H. Munificence and Carrying Capacity of the Environment and Organization Formation. Entrep. Theory Pract. 1993, 17, 77. [CrossRef]

20. Arrow, K.; Bolin, B.; Costanza, R.; Dasgupta, P.; Folke, C.; Holling, C.S.; Jansson, B.O.; Levin, S.; Mäler, K.G.; Perrings, C.; et al. Economic Growth, Carrying Capacity, and the Environment. Science 1995, 268, 520-521. [CrossRef]

21. Trakolis, D. Carrying capacity-An old concept: Significance for the management of urban forest resources. New Medit 2003, 3, 58-64.

22. Martire, S.; Castellani, V.; Sala, S. Carrying capacity assessment of forest resources: Enhancing environmental sustainability in energy production at local scale. Resour. Conserv. Recycl. 2015, 94, 11-20. [CrossRef]

23. Ng, K.L.; Obbard, J.P. Strategic environmental assessment in Hong Kong. Environ. Int. 2005, 31, $483-492$. [CrossRef] [PubMed]

24. Liu, H. Comprehensive carrying capacity of the urban agglomeration in the Yangtze River Delta, China. Habitat Int. 2012, 36, 462-470. [CrossRef]

25. Zheng, D.; Zhang, Y.; Zang, Z.; Sun, C. Empirical research on carrying capacity of human settlement system in Dalian City, Liaoning Province, China. Chin. Geogr. Sci. 2015, 25, 237-249. [CrossRef]

26. Cheng, J.Y.; Zhou, K.; Chen, D.; Fan, J. Evaluation and Analysis of Provincial Differences in Resources and Environment Carrying Capacity in China. Chin. Geogr. Sci. 2016, 26, 539-549. [CrossRef]

27. Dong, C.; Li, M.; Chen, Z.; Jiang, X.; Chen, Y. Land use scenario simulation based on multi-agent system. In Proceedings of the International Conference on Geoinformatics, Shanghai, China, 24-26 June 2011.

28. Cheng, Q.; Jiang, P.; Cai, L.; Shan, J.; Zhang, Y.; Wang, L.; Li, M.; Li, F.; Zhu, A.; Chen, D. Delineation of a permanent basic farmland protection area around a city centre: Case study of Changzhou City, China. Land Use Policy 2017, 60, 73-89.

29. Gao, Y.; Ma, L.; Liu, J.; Zhuang, Z.; Hang, Q.; Li, M. Constructing Ecological Networks Based on Habitat Quality Assessment: A Case Study of Changzhou, China. Sci. Rep. 2017, 7, 46073. [CrossRef]

30. Cheng, L.; Jiang, P.H.; Li, M.C.; Wang, L.; Gong, Y.; Pian, Y.; Xia, N.; Duan, Y.; Huang, Q. Farmland protection policies and rapid urbanization in China: A case study for Changzhou City. Land Use Policy 2015, 48, 552-566.

31. Furuya, K. Environmental carrying capacity in an aquaculture ground of seaweeds and shellfish in Sanriku coast. Bull. Fish. Res. Agency 2004, 1, 65-69. 
32. Thompson, S.; Treweek, J.R.; Thurling, D.J. The Potential Application of Strategic Environmental Assessment (SEA) to the Farming of Atlantic Salmon (Salmo salar L.) in Mainland Scotland. J. Environ. Manag. 1995, 45, 219-229. [CrossRef]

33. Xu, X.Y.; Huang, X. The Study on Population Carrying Capacity of Yangtze River Economic Belt Based on Carbon's Peak Values. Modern Urban Res. 2016, 65, 21-30. (In Chinese)

34. Clarke, A.L. Assessing the Carrying Capacity of the Florida Keys. Popul. Environ. 2002, 23, 405-418. [CrossRef]

35. Wang, J.J.; Yao, X.H.; Li, J.R.; Chang, H.; Wang, Y.G. Assessment for Ecological Carrying Capacity of Heihe River Basin. Res. Environ. Sci. 2000, 13, 44-48. (In Chinese)

36. Prato, T. Fuzzy adaptive management of social and ecological carrying capacities for protected areas. J. Environ. Manag. 2009, 90, 2551-2557. [CrossRef] [PubMed]

37. Hardin, G. Cultural carrying capacity: A biological approach to human problems. BioScience 1986, 36, 599-604. [CrossRef]

(C) 2019 by the authors. Licensee MDPI, Basel, Switzerland. This article is an open access article distributed under the terms and conditions of the Creative Commons Attribution (CC BY) license (http://creativecommons.org/licenses/by/4.0/). 